\title{
Autoimmune hemolytic anemia warm-antibody type (Warm AlHA) in an 8-year-old Balinese girl
}

\author{
Putu Tri Yasa, Ida Bagus Mudita, Hendra Santoso, Sudaryat Suraatmadja \\ Department of Child Health, Medical School, Udayana University, Sanglah Hospital, Denpasar
}

\begin{abstract}
ABSTAACT A case of autoimmune hemolytic anemia warm antibody type A (warm AlHA) in an 8-year-old Balinese girl was reported. The diagnosis was established based on clinical teatures, laboratory findings including positive Coombs' test positive. The etiology was probably primary or idiopathic. The child was transfused with packed red cells and treated with oral prednisone. The response of the treatment was good and she experienced complete remission. The prognosis in patients with idiopathic warm AIHA are unpredictable. The girl underwent further follow-up in the child hematologic division every two weeks. [Paediat Indonas 2001;41:64-68]
\end{abstract}

Keywords: autoimmune disease, anemia, hemolysis

Autoimmune hemolytic anemia warm-antibody type (warm AIHA) is a disorder of the immune system in which normal erythrocytes are attacked and destroyed by antibudies.' It is characterized by antibody (IgG) and complement mediated lysis, with the autoantibody maximally active at body temperature of $37^{\circ} \mathrm{C} .{ }^{2} \mathrm{AIHA}$ is a relatively uncommon disorder. The annual incidence is estimated to be 1 per 80.000 people. ${ }^{1,2}$ Seventy to eighty percent of these cases are due to warm AIHA, 10-20\% are due to cold AIHA, and 2. $5 \%$ are due to paroxysmal cold hemoglobinuria (PCH). Approximately $50 \%$ of the patients with wann AIHA have an associated disease, such as malignancy, systemic lupus erythematosus, or leukemia. Warm AIHA may occur idiopathically or may be induced by drugs such as penicillins, cephalosporins, phenacetin, quinidine, or alpha-methyldopa. ${ }^{1,3,4}$

The bases of diagnosis of warm AIHA are shortened red blood cells (RBC) survival, evidence of the

Correspondence: Putu Tri Yasa, MD, Department of Child Health, Medical School, University of Udayana, Denpasar, Bali, Indonesia. host's antibodies that are reactive to autologous RBC with autoantibody active at body temperature of $37^{\circ} \mathrm{C}$, most frequently demonstrated by a positive Coombs' test. A positive direct Coombs' test indicates autoantibody mediated hemolysis, while a positive indirect Coombs' test points to the presence of alloantibody. $1.3,5$ The purpose of this paper is to report a case of autoimmune hemolytic anemia warm antibody type (warm AIHA) in an 8-year-old Balinese girl.

\section{Report of the Case}

An 8-year-old Balinese girl was admitted to the Department of Child Health, Medical School, Udayana University, Sanglah Hospital, Denpasar, on March 1, 1999 with the chief complaints of pallor and fatigue since a few weeks. Initially the symptoms were mild which then became worse. She also had dizziness, light headache, weakness, jaundice, and dark-colored urine since three days before treated. There was no history of fever, dyspnea, malaria, petechiae, or bleeding, nor evidence of blood loss, transfusion, snake bites, or use of drugs. 
On physical examination she looked fatiguc with the blood pressure of the superior extremity of $110 / 80$ $\mathrm{mmHg}$, the pulses were eyual and regular at 98/ minute, respiratury rate $26 /$ minute, axillary temperature $37^{\circ} \mathrm{C}$, bxily weight $20 \mathrm{~kg}$, height $122 \mathrm{~cm}$ and was well-nourished. The conjunctiva was anemic and the sclera was jaundiced. The neck was normal. Chest examinationrevealed no abnormalities; both sides were symmetrical, breath sound was normal and cardiac murmur was negative. It was found that she had hepatomegaly (palpahle 1/3-1/3, suuffle and sharp margin), and muderate splenomegaly.

Results of hluxd analysis revealed hemoglubin 4.9 $\mathrm{g} / \mathrm{dl}$, hematocrit $9.7 \%$, red hlood cells $900,000 / \mu \mathrm{L}$, MCV 108 月, MCH 54.3 pg, MCHC 50.3 g/dl, WBC (white blood cells) count $6800 / \mu \mathrm{L}$, differential

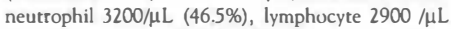
(43.0\%), monucyte $500 / \mu \mathrm{L}(7.7 \%)$, eusinuphil $100 /$ $\mu \mathrm{L}(2.1 \% \mathrm{E})$, basuphil $100 / \mu \mathrm{L}(0.8 \%)$, and platelet $368,000 / \mu \mathrm{LL}$. Blond smear shuwed normuchrunic, normucytic erythrucytes, spherocytes, anisucytusis, polychromasia, nonnal leukocytes and thrombocytes.

The working diagnosis was severe anemia (suspected hemolytic anemia). It was planned to do investigation of liver function test (LFT), reticulocytc count, G6PD, Coombs' test, serum iron/IBC/TIBC, malaria, $\mathrm{HbsAg}$, urine and feces. She was treated with multivitamin, I teaspoon two times daily. On March 2, 1999 she was still pallor, jaundiced, and excreted dark urine. Results of the liver function test showed total bilirubin $4.97 \mathrm{mg} / \mathrm{dl}$ (normal value: $0-1.00$ ), direct bilirubin $0.25 \mathrm{mg} / \mathrm{dl}$, SGOT $60 \mathrm{U} / \mathrm{L}$, SGPT $10 \mathrm{U} /$ $\mathrm{L}$, alkaline phosphatase $153 \mathrm{mg} / \mathrm{dl}$, cholesterol $170 \mathrm{mg} /$ $\mathrm{dl}$, albumin $4.89 \mathrm{~g} / \mathrm{dl}$ and globulin $4.58 \mathrm{~g} / \mathrm{dl}$. Reticulocyte count was $26.0 \%$ (N $0.5-1.5 \%$ ). The iron analysis revealed serum iron $42 \mathrm{mg} / \mathrm{dl}$ ( $\mathrm{N}: 49-151)$, iron binding capacity $143 \mathrm{mg} / \mathrm{dl}(\mathrm{N}: 180-260)$, and total iron binding capacity $185 \mathrm{mg} / \mathrm{dl}$ ( $\mathrm{N}$ : 380-400). Blood examination for malaria was negative, stool examination gave normal resuls. Urine profile: leukocyte 15/ $\mu \mathrm{L}$, negative nitrite, $\mathrm{pH} 6$, negative protein, normal glucose, negative ketone, urobilinogen: $46 \mathrm{mg} / \mathrm{L}$ $(++)$, bilirubin $>5 \mathrm{mg}$, erythrocyte $10 / \mu \mathrm{L} . \mathrm{HBsAg}$ was negative. To find out the cause of hemolytic anemia we did hemoglobin electrophoresis, G6PD erythrocyte, bone marrow and Coombs' test. She was treated with PRC (packed red cells) transfusion $560 \mathrm{ml}(200 \mathrm{ml}$ one time daily for three days) and multivitamin.
On March 5, 1999, the jaundice and pallor were minimal. Result of $\mathrm{Hb}$ electrophoresis: $\mathrm{Hb}$ Al $96 \%$, $\mathrm{Hb} \mathrm{A} 25 \%$ and $\mathrm{Hb} \mathrm{C}, \mathrm{Hb} \mathrm{F}$, and $\mathrm{Hb} \mathrm{S} 0 \%$ (in normal limits), G6PD erythrocyte: $125 \mathrm{mU} / 109$ (N: 118-144 $\mathrm{mU} / 109$ erythrocytes). Direct Coombs' test was positive. Bone marrow profile was hypercellular with increased activity of erythrocyte system, myeloid and megakaryocyte systems were normal. These meant that the hemolytic process occurred in the bone marrow. Results of blood analysis showed $\mathrm{Hb} 10 \mathrm{~g} / \mathrm{dl}, \mathrm{HCT}$ $22.6 \%$, WBC $5800 / \mu \mathrm{L}$ and platelets $202,000 / \mu \mathrm{L}$.

The definitive diagnosis was autoimmune hemolytic anemia warm-antibody type (warm AIHA). Subsequently the patient was treated with oral dose of $1.5 \mathrm{mg} / \mathrm{kg} \mathrm{BW} /$ day prednisone (body weight $20 \mathrm{~kg}$ ), which made dose of $30 \mathrm{mg} /$ day divided into three doses given three times daily and multivitamin. On March 12,1999 the patient showed close to normal clinical features. The urine was clear and had yellow color. Liver and spleen were not palpable. Results of blood

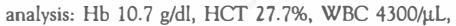
platalets $300,000 / \mu \mathrm{L}$. Urine bilirubin was negative. Liver function test: total bilirubin $1.88 \mathrm{mg} / \mathrm{dl}$ and direct bilirubin $0.25 \mathrm{mg} / \mathrm{dl}$. She was then treated with prednisone, $1 \mathrm{mg} / \mathrm{kg} \mathrm{BW} /$ day, divided into two doses.

On March 17, 1999, the patient was discharged from the hospital, with blood analysis: $\mathrm{Hb} 11.8 \mathrm{~g} / \mathrm{dl}$, HCT $32.1 \%$, RBC 3,580,000 / $/ \mathrm{L}$, WBC 5000/ $\mathrm{LL}$, platelets $217,000 / \mu \mathrm{L}$, total bilirubin $0.99 \mathrm{mg} / \mathrm{dl}$ and direct bilirubin $0.20 \mathrm{mg} / \mathrm{dl}$. She was referred to the outpatient clinic of the Hematologic Division.

On March 24, 1999, the patient was in good condition with the result of blood analysis: $\mathrm{Hb} 12 \mathrm{~g} / \mathrm{dl}$, HCT $36 \%$, WBC $6500 / \mu \mathrm{L}$, platalets $300,000 / \mu \mathrm{L}$, reticulocyte count $12 \%$, total bilirubin $0.99 \mathrm{mg} / \mathrm{dl}$ and direct bilirubin $0.20 \mathrm{mg} / \mathrm{dl}$. She was treated with oral dose of $0.5 \mathrm{mg} / \mathrm{kg}$ BW/day prednisone, and was continued follow-up every two weeks in the Pediatric Hematology Outpatient Clinic.

\section{Discussion}

The diagnostic approach to hemolytic anemia is based on the understanding of the physiology of hematopoiesis. In the case of hemolysis, bone marrow can compensate for shortened red blood cell survival. This in turn can be clinically detected by an increase in the reticulocyte count. Hemulysis itself can be 
caused by immune mediated processes (e.g., autoimmune hemolytic anemia), defects in red blood cells (RBC) membrane (e.g., hereditary spherocytosis), derangements in RBC enzyme machinery (e.g., G6PD deficiency), failure in the synthesis of hemoglobin moleculcs (e.g., thalassemia or sickle cell disease), or a mechanical disruption of erythrocytcs (e.g., microangiopathic hemolytic anemia). ${ }^{6.9 .10}$

Autoimmune hemolytic ancmia (AIHA) is characterized by the presence of autoantibodies, which in turn causes short red blood ccll survival. ${ }^{2}$ AIHA is divided into threc classes on basis of serologic autoimmune process; warm AIHA which is characterized by antibody (IgG) and complement mediated lysis, autoantibody maximally active at body temperature of $37^{\circ} \mathrm{C}$, cold AIHA which is characterized by antibody (IgM) and complement mediated lysis, autoantibody active at temperatures below $37^{\circ} \mathrm{C}$, and mixed cold and warm autoantibodies. It is also uscful to classify AIHA based on the presence or absence of underlying diseases. When no recognizable underlying disease is present, the AIHA is tcrmed primary or idiopathic. When AIHA appears to be a manifestation or complication of an underlying disorder, the term sccondary AIHA is applied. ${ }^{3.7 .9}$

In our case, the diagnosis of warm AIHA was based on clinical manifestations and laboratory findings, including positive Coombs' test.

The anemia of warm AIHA is frequently severe with an initial hemoglobin lcvel of $7 \mathrm{~g} / \mathrm{dl}$ or less. Progression of the anemia frequently occurs before therapy becomes effective. The reticulocyte count is usually elevatcd. Evaluation of the blood film can reveal several features related to AIHA. Polychromasia indicates rcticulocytosis, reflecting an increased rate of reticulocytc process from the marrow. Spherocytes are seen in patients with moderate to severe hemolytic anemia. Hyperbilirubinemia is highly suggestive of hemolytic anemia, although its absence does not cxclude the diagnosis. Total bilirubin is only modestly increascd, up to $5 \mathrm{mg} / \mathrm{dl}$ with rare exceptions, the conjugated (direct) fraction constitutes less than 15 percent of the total bilirubin. Urinary urobilinogen is increased regularly, but bile is not detected in the urine unless serum conjugated bilirubin is increased. ${ }^{2 \cdot}$ 4

A polyspecific Coombs' antiserum or Coombs' tcst that contains antibodies to human immunoglobulin and complement components is added to a washed suspension of the patient's red cells. The appearance of agglutination indicates membranc-bound immunoprotein and is a presumptive evidence of an immune hemolytic disorder. In warm AIHA, the patient's red cells are almost always coated with either IgG, C3d, or both. Coombs' test detects the presence of immunoproteins (immunoglobulin of fragment of activated complement) that have adhered to the red cells. ${ }^{5,6}$ The cardinal feature of immunc hemolytic anemia is a positive direct Coombs' test or direct antiglobulin test (DAT). In more than $95 \%$ of the patients with immunc hemolysis, the direct Coombs' test is positive. In less than $5 \%$ the test is ncgative.

TABLE 1. MOST COMMON PRESENT SIGNS AND SYMPTOMS IN PATIENTS WITH AIHA OF THE WARMREACTIVE ANTIBODY TYPE ${ }^{\circ}$

\begin{tabular}{|c|c|c|c|c|c|}
\hline Symptom & Freq. $(\%)$ & our case & Sign & Freq. (\%) & our case \\
\hline Weakness & 88 & + & Splenomegaly & 82 & + \\
\hline Dizziness & 50 & + & Hepatomegaly & 45 & + \\
\hline Fever & 37 & - & Lymphadenopathy & 34 & - \\
\hline Jaundice & 21 & + & Jaundice & 21 & + \\
\hline Bleeding & 10 & - & Thyromegaly & 10 & - \\
\hline Dyspnea & 9 & + & Edema & 6 & - \\
\hline Cough & 6 & - & Cardiac failure & 5 & - \\
\hline Weight loss & 5 & - & Pallor & 4 & + \\
\hline Gastrointestinal disturbance & 5 & - & & & \\
\hline Anorexia & 4 & + & & & \\
\hline Dark urine & 3 & + & & & \\
\hline Angina & 2 & - & & & \\
\hline Confusion & 2 & - & & & \\
\hline
\end{tabular}


In general, most AIHA is secondary while the frequency of idiopathic AIHA is probably close to $50 \%$ of all cases. In idiopathic AlHA, splenomegaly occurs in $50-60 \%$ of the patients, hepatomegaly in $30 \%$, and lymphadenopathy in about $25 \%$. Only about $25 \%$ of the patients have no enlargement of the spleen, liver, or lymph nodes. Based on serologic findings, 70 80 percent of these cases are due to warm AII 1 A, 10. $20 \%$ are duc to cold AlHA, and $2-5 \%$ arc duc to paroxysmal cold hemoglobinuria (PCH) ${ }^{4.5 .6}$

In our case the clinical manifestations were pallorr, fatigue, wcakness, dizziness, light-headache, anemia, jaundice, hepatosplenomegaly, and dark urinc. The laboratory results were low hemoglobin level (4.9 $\mathrm{g} / \mathrm{dl})$, low hematocrit $(9.7 \%)$, increased reticulocytc count $(26.0 \%)$, and $\mathrm{RBC}$ characteristics showed hypochromic, macrocytic crythrocytc, spherocyte, anisocytosis and polychromasia. It meant that severc hemolytic anemia with an increasc of hemopoicsis process occurred in the bone marrow. The liver function test showed total bilirubin of $4.97 \mathrm{mg} / \mathrm{dl}$, direct bilirubin $0.25 \mathrm{mg} / \mathrm{dl}$, and urine urobilinogen $46 \mathrm{mg} / \mathrm{L}$ $(++)$. These indicated intravascular hemolysis process. The result of direct Coombs' test was positive, indicating that autoantibody ( $\lg \mathrm{G})$, complement, or both were detected.

The etiology of AlHA is unknown. It has been diagnosed in pcople of all ages, from infants to the elderly. Warm AlHA with specificity for red cell antigens have been described in association with many discases, including viral infections, malignancics, immunc deficiency states, and autoimmunc disorders, such as lupus crythematosus. The ultimate cause of the autoimmune phenomena has yet to be identificd; however, scveral contributing factors have been discovered, including an appropriate genetic predisposition and a fundamental disorder of immunologic regulation in affected individuals. . $^{3.4 .6}$

In our case, the differential diagnoses are hereditary hemolytic anemias and hereditary spherocytosis (HS). Family studics of patients with HS, howcver, usually can identify other affected individuals. Glucose-6-phosphate dehydrogenasc (G6PD) deficiency is the most common enzymopathy of the pentosc phosphate pathway. It can manifest in threc forms; nconatal jaundice, the most scverc form, where exchange transfusion may be life-saving; a mild form of this deficiency, G6PD A-variant, the most common type present in American blacks; the severe form of the deficiency, G6PD Mediterranean. Most importantly, the RBC of the patients with congenital hemolytic ancmia gencrally do not have a positive direct Coombs' test reaction. Cold AlHA are characterized by autoantibody (IgM) and complement mediated lysis, with autoantibudy active at temperatures below $37^{\circ} \mathrm{C}$. Paroxysmal cold hemoglobinuria ( $\left.{ }^{P} \mathrm{CH}\right)$ has specificity for found Donath-Landsteincr antibody. We didn't find any sccondary causc or other diseases, including thalasscmia, hereditary spherocytosis (HS), G6PD deficiency, PCH and Cold AIHA, or history of AlHA inducing drug usc. Accordingly we assume that our casc might be of idioparhic type.

Corticosteroids are the initial therapy for paticnts with warm AlHA. An appropriate regimen is pred-

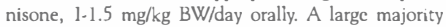
of paticnts show a clinical response within 2 wecks of treatment, and a complete lack of response at day 21 should be considered as stcroid failure. For those who respond to corticosteroids, a normal or stable hematocrit and reticulocyte count are found in 30-90 days. At this time the dose of prednisone should be reduced wcekly by $0.5 \mathrm{mg} / \mathrm{kg} \mathrm{BW/day}$ or by 10 to $20 \mathrm{mg} /$ day. Alternate-day therapy may bc used with the dose of less than $30 \mathrm{mg} / \mathrm{day}$. Some patients may be maintained on acceptably low doses of prednisone, but if more than $10-15 \mathrm{mg} /$ day is required to keep the hematocrit at an acceptable level, the response should be considered inadequate and other treatment should be strongly considered. The decision regarding the use of other therapics should be made within several months after diagnosis to prevent the adverse cffects of long-term corticosteroid administration. Treatment with danazol has usually been used in conjunction with prednisone either as initial therapy or aftcr inadequate response to corticosteroids alone. Danazol may be used in a dose of $600-800 \mathrm{mg} / \mathrm{day}$. Once remission is sustained the dose of danazol may be reduced to $200-400 \mathrm{mg} /$ day. $^{2.4 .5}$

Transfusion therapy must never be considered as an contraindication, even though the crossmatch test may be strongly incompatiblc. When life-threatening manifestation of anemia is present, transfusion is mandatory, even at hemoglohin level of $5.8 \mathrm{mg} / \mathrm{dl} .^{2,1}$

Our patient was treated with packed red cells (PRC) transfusion; $200 \mathrm{ml}$ per day for thrce days, because of low hemoglobin level. Subsequently the pa- 
tient was treated with oral dose of $1.5 \mathrm{mg} / \mathrm{kg} \mathrm{BW} /$ day prednisone. The dose of prednisone was reduced 0.5 $\mathrm{mg} / \mathrm{kg} \mathrm{BW/day} \mathrm{every} \mathrm{two} \mathrm{weeks,} \mathrm{and} \mathrm{this} \mathrm{patient} \mathrm{was}$ maintained on low dose of prednisone. The treatment response was good.

Splenectomy, if the response of corticosteroids is inadequate, should be performed unless surgery is strongly contraindicated. Approximately $50.75 \%$ of the patients showed marked improvement or had complete hematologic remission after splenectomy. Remission are not always permanent, however, and relapse may occur months or years later. If an incomplete remission or a relapse occurs following splenectomy, much lower corticosteroid Joses may prove effective in controlling the disease activity. ${ }^{2+1.5}$

Immunosuppressive drugs may be given to patients whose hemolysis are inadequately controlled by steroid and splenectomy. Oral azathioprine (Imuran), $50-200 \mathrm{mg} / \mathrm{day}$ or cyclophosphamide (cytoxan), 50-150 mg/day, is commonly used. If the drug is tolerated by the patient, it is reasonable to continue treatment for up to 6 months while waiting for a response. When response occurs the patient may be slowly weaned from the drug. If there is no response, the alternative drug may be given. ${ }^{2,3}$

The prognosis in patients with idiopathic warm AIHA have unpredictable clinical courses characterized by relapses and remissions. No particular feature of the illness has been a consistent predictor of outcome. A minority of paticnts have complete resolution of their disease and others have a chronic but manageable course. The estimated mortality of patients followed up for 5.10 years is $15-25 \% .{ }^{3.6}$ In our case; the patient had complete resolution of her disease.

\section{References}

1. Mudge-Grout CL. Hemopoietic disorders (autoimmune hemolytic anemia) In: Immunologic disorders. St Louis: Moshy, 1992.p. 209-11.

2. Mentzer WC. Autoimmune hemolytic anemia. In: Rudolph AM, editor. Rudolph Pediatrics. 26th ed. San Francisco: Appleton \& Lange, 1996. p. 1201-2.

3. Stockman JA. Hemolytic anemias resulting from abnormalities of the red blood cell produced by extrinsic factors. In. Behrman RE, Kliegman RM, Nelson WEet al, editors. Nelson Textbook of pediatrics. 40thed. Philadelphia: WB Saunders, 1992. p. 1254-6.

4. Kaplan ME, Allen DW, Petz LD. Hemolytic ancmia: congenital and acquired. In: Mazza JJ, editor. Manual of clinical hematology. 2nd ed. Boston: Little Brown and Conpany, 1994. p. 87-114.

5. Richard LG. The hemolytic disorders: General considerations. In: Richard LG, Bithell TC, Foerster J, et al. Wintrobe's clinical hematology. 9th ed. London: Lea \& Febiger, 1993. p. 944-62.

6. Packman $\mathrm{CH}$, Ieddy JP. Acquired hemolytic anemia due to warm-reacting autoantibodies. In: Beutler $E_{1}$ Lichtman MA, Coller BS, Kipps TJ, editors. Williams hematology. 5 th ed. New York: McGraw.Hill, 1995. p. 677-84.

7. Gill FM, Schreiber AD. Autoimmune hemolytic anemia. In: Nathan DG, Oski FA, editors. Hematology of infancy and childhood. Philadelphia: WBSaunders, 1987.p. 413-25.

8. Kocher WD. Autoimmmune hemolytic anemia. In: Simson E, Ross DW, editors. Atlas of automated cytochemical hematology. Philadelphia: WBSaunders, 1988. p. 26-9.

9. Shafer FE, Sribel NL, Reaman GH. Hematology disorders. In: Peter R, editor. Textbook of pediatric critical care. 3rded. Philadelphia: WB Saunders, 1993.p. 743-67.

10. Djulbegovic B. Autoimmune hemolyticanemia (Coombs'. positive). In: Reasoning and decision making in hematology. New York: Churchill Livingstone, 1992, p. $51-6$. 